\title{
PHYSICAL QUALITY OF THE FIRST EGG OF JAPANESE QUAIL (Coturnix japonica L.) AFTER GIVEN LIQUID HERBAL CONCOCTION
}

\author{
Hasan Basri*, Meilinda Pahriana Sulastri \\ Biology Study Program, Faculty of Mathematics and Natural Sciences, Al-Azhar Islamic \\ University, Mataram, Indonesia \\ *hasanbasri7491@gmail.com
}

Doi: 10.31943/mangiferaedu.v5i2.98

Received: May 30, 2020 Accepted: November 25, 2020 Published: January 31, 2021 Citation: Basri, H., \& Sulastri, M. P. (2021). Physical Quality of The First Egg of Japanese Quail (Coturnix japonica L.) after Given Liquid Herbal Concoction. Jurnal Mangifera Edu, 5(2), 121-130.

\begin{abstract}
This study aims to determine the first egg's physical quality in Coturnix japonica L. after being given a liquid. The study is an experimental study with a Completely Randomized Design. In this study, the test animals were 24 Coturnix japonica $L$. randomly selected from 42 quail with 12 days old and average body weight of $\pm 37.67 \mathrm{~g}$. They have been selected are divided into four treatment groups, i.e., P0: a control group with untreated drinking water, P1: $3 \mathrm{ml} /$ liter water, P2: $6 \mathrm{ml} /$ liter water, P3: $9 \mathrm{ml} /$ liter water. Each treatment group consisted of 6 replications. Variables analyzed included egg weight, eggshell weight, yolk weight, albumen weight, egg yolk index, and egg quality index. The results showed that the addition of herbal concoction with the treatment of $3 \mathrm{ml}, 6 \mathrm{ml}$, and $9 \mathrm{ml}$ per 1 liter of drinking water on the physical quality of the first egg of Coturnix japonica L. including egg weight, yolk weight, albumen weight, shell weight, egg quality index, and yolk index statistically showed results were not significantly different $(P>0.05)$, but the addition of herbal concoction did not have a negative effect on the physical quality of the first eggs of Coturnix japonica $L$.
\end{abstract}

Keywords: First egg, Japanese quail, Liquid herbal, Physical quality

\section{INTRODUCTION}

The increasing population of Indonesia has led to an increase in food, vegetables, and animals. To meet food needs, especially animal food sources, further study is needed to find food sources that produce easily, cheaply, and quickly. Poultry eggs and meat are a source of nutrition that can meet the nutritional needs of the community. Japanese quail (Coturnix japonica L.) is a bird with a relatively small body size and short legs. Japanese quail is one of the livestock that is being developed in Indonesia (Saputro, 2011). Japanese quail is poultry that has various advantages that can be utilized by a human. Some of the advantages including a fast egg production age, low capital, easy and short maintenance, and 


\section{Jurnal Mangifera Edu, Volume 5, Issue 2, January 2021, 121-130}

does not require large areas (McBride et al., 2015), laying time between 40-45 days and can produce 250-300 eggs per year, and requires less feed. Besides, the price of quail meat and eggs is relatively lower compared to other poultry eggs. The nutritional content of Japanese quail eggs include: vitamin A of $543 \mu \mathrm{g}$ (per $100 \mathrm{~g}$ ), omega-3 0.44\%, omega-6 1.62\%, Ca (51.89 mg/100gr), Fe (2.65 mg/100gr), Cu (0.104 mg/kg) and Zn (1.04 mg/kg) (Suripta \& Astuti, 2007; Dudusola, 2010; Basri et al., 2018). One part of quail eggs is albumen.

Albumen is part of an egg that protects yolk. Yair \& Uni (2011) states that yolk contains food that is very important in embryonic development. Meanwhile, to increase quail egg production, seeds, feed, and management need to be improved. One alternative in Japanese quail management by providing additional feed in the form of feed concoctions.

The herbal concoction is a feed additive with a composition of $100 \%$ sourced from spices, and the production process is both traditional and modern. According to Zurahmah (2000); Agustina et al. (2017), stated the ingredients in both fresh and dry form are called Simplicia, such as root rhizomes, leaves, stems, and fruits. The materials used in this study were: turmeric, curcuma, ginger, betel leaves, papaya leaves, garlic, cinnamon, brown sugar, EM4, and water.

The main chemical content of turmeric is curcumin. This compound is a derivative of curcuminoids together with desmetoksicurcumin and bidesmetoksicurcumin. Turmeric also contains essential oils, such as ketones, sesquiterpenes, turmerone, tumeon, zingiberene, felanderen, sabinene, borneol sineil. Also, turmeric contains secondary and primary metabolites. The primary metabolite compounds of turmeric consist of carbohydrates, fats, proteins, vitamin $\mathrm{C}$, and mineral salts, such as iron, phosphorus, and potassium (Mughal, 2019). The results of the study on the addition of turmeric powder supplements in Japanese quail feed of $54 \mathrm{mg} / \mathrm{head} /$ day before sexual maturity was able to increase lipid metabolism, distribution to various organs, ovarian follicles, reducing abdominal fat deposits, lowering cholesterol levels in blood and eggs (Saraswati et al., 2013).

Curcuma is an herbal plant and natural antibiotics (Anjusha \& Gangaprasad, 2014). The bioactive compound in Curcuma is xanthorrhizol, known as an antibacterial that can prevent disease in livestock. This bioactive material can inhibit the growth of pathogenic bacteria. According to Rukayadi \& Hwang (2007), the effectiveness of Curcuma xanthorrhizol is the same as commercial antifungals such as amphotericin B. Yustin et al. (2014) stated that the addition of Curcuma rhizome flour in feed could increase the percentage of the carcass. Another study by (Widodo, 2019) stated that the optimal use of Curcuma for $2 \%$ in feed could increase chickens' body weight. 
The study results by Setyanto et al. (2012) found an effect of ginger flour on the feed rate. Harmono \& Andoko (2005) stated that the stimulation of the mucous membranes of the large stomach and intestines by the essential oils released by ginger rhizomes causes the stomach to become empty chicken will consume the feed.

The previous study results showed that the addition of betel leaf flour as a feed additive significantly reduced cholesterol levels in broiler chicken meat. The lowest cholesterol levels were obtained by giving betel leaf flour a level of $0.7 \%$, with $14 \mathrm{mg} / \mathrm{dl}$ (Lodang et al., 2020).

Papaya leaves contain papain enzymes, carpaine alkaloids, pseudo carpain, glycosides, carposides, saponins, sucrose, and dextrose. Most alkaloids are solid substances, bitter taste and difficult to dissolve in water but easily dissolve in chloroform, ether, and other relatively nonpolar organic solvents (El-Sakka, 2010). Giving papaya leaves starting from the starter phase can reduce the mortality of native chickens. Sukoco et al. (2019) stated that adding papaya leaves and rice husks as fiber feed with starnox supplementation can reduce subcutaneous fat, including skin, and increase the percentage of carcass bones.

Studies on herbs used for poultry feed have been widely carried out, including turmeric, betel leaf, and ginger, to broilers' lipid profile status under normal physiological conditions (Basri \& Swandayani, 2019). Giving ginger juice to quails given through drinking water resulted in average egg production, and the resulting feed conversion value was better than previous studies (Rinawidiastuti et al., 2019). According to Çabuk et al. (2014), supplementation of "herbal medicine" increases quail egg production. Egg quality is known by measuring the Yolk Index (IKT) and Haugh Unit (HU). Nasution (2017) stated that papaya leaf flour feed could improve Japanese quail eggs' quality. This study aims to determine the first egg's physical quality in Japanese quail after being given a liquid herbal concoction.

\section{RESEARCH METHOD}

This study was conducted at Biology Laboratory, Al-Azhar Islamic University Mataram, and Hepatika Laboratory, Mataram. All equipment, materials, and places to be used are prepared. Japanese quail was obtained from breeders in Puyung Village, Central Lombok Regency.

Prepare a collective cage of $1 \mathrm{~m}^{2}$ and equipment that has been fumigated with disinfectant. Acclimation is carried out for seven days. Then the Japanese quails are put into 
a collective cage with ten cages formation. A sugar solution with a concentration of 1 tablespoon in 1 liter of water is given to restore the Japanese quail condition.

This study's herbal ingredients are mixtures of various ingredients such as turmeric, curcuma, ginger, betel leaf, garlic, cinnamon, brown sugar, EM4, and water. The process of making an herbal concoction with all herbal ingredients is weighed in a fixed amount. The composition of herbal ingredients includes turmeric $250 \mathrm{~g}$; curcuma $400 \mathrm{~g}$; ginger $250 \mathrm{~g}$; betel leaf $250 \mathrm{~g}$; papaya leaves $250 \mathrm{~g}$; garlic $500 \mathrm{~g}$; Cinnamon $250 \mathrm{~g}$; $500 \mathrm{~g}$ brown sugar, and $500 \mathrm{ml} \mathrm{EM} 4$. All ingredients are washed and thinly sliced. Then blend until smooth and diluted using 10 liters of warm water, then stir until well blended and filtered, stored for seven days for the fermentation process. Herbal concoctions ready to be given to quails.

The company that produces the feed used in this study is PT CHAROEN POKPHAND INDONESIA. The levels of the nutritional composition of the feed are presented in Table 1.

\begin{tabular}{lc} 
Tabel 1. Content of nutritional component of the feed \\
\hline Nutritional Component & Amount \\
\hline Water Rate & $13.00 \%$ \\
Protein & $20.00-22.00 \%$ \\
Fat & $5.00 \%$ \\
Fiber & $5.00 \%$ \\
Ash & $7.00 \%$ \\
Calcium & $0.90 \%$ \\
Phosphor & $0.60 \%$ \\
Aflatoxin & $50 \mathrm{ppb}$ \\
\hline \multicolumn{2}{c}{ (PT. Charoen Pokphand Indonesia) }
\end{tabular}

This study is an experimental study with a completely randomized design (CRD). Determination of test animals at each treatment was chosen randomly. In this study, test animals were 24 Japanese quail (Coturnix japonica L.) randomly selected from 42 quail with 12 days old and average body weight of $\pm 37.67 \mathrm{~g}$. The Japanese quails that have been selected are divided into four treatment groups, i.e., P0: a control group with untreated drinking water, P1: treatment group with $3 \mathrm{ml}$ liquid herbal per 1 liter drinking water, $\mathrm{P} 2$ : treatment group with $6 \mathrm{ml}$ liquid herbal per 1-liter drinking water, P3: treatment group with $9 \mathrm{ml}$ liquid herbal per 1 liter drinking water. Each treatment group consisted of six replications. Variables analyzed included egg weight, eggshell weight, yolk weight, albumen weight, egg yolk index (IKT), and egg quality index. 
The variables observed in this study are:

a. Egg Weight

Egg weight was obtained by weighing the first quail eggs. After 45 days of age, the quails began laying eggs. The eggs were collected and then weighed using a scale with a sensitivity of $0.1 \mathrm{~g}$.

b. Egg Shell Weight

The weight of the eggshell is obtained by weighing the eggshell using a digital scale.

c. Yolk weight

Yolk weights are obtained by weighing yolk using a digital scale.

d. Albumen weight

Albumen weights obtained by weighing albumen using a digital scale.

e. Egg Yolk Index (IKT)

A yolk index is a unit that shows the quality of the yolk. Measurement of the yolk index by measuring the yolk index of the first egg. The components used to measure the yolk index were the yolk height and diameter. The height of the egg yolk is measured by breaking the egg on a flat plane, and then the height is measured using a tripod micrometer modification tool, namely by inserting a toothpick into the egg yolk on the highest surface then marking the height limit of the egg yolk visible on the toothpick, then measured using a caliper. The values obtained are recorded and calculated using the following formulation Standar Nasional Indonesia (2006).

$$
\mathrm{IKT}=\frac{\text { Egg yolk height }}{\text { Egg yolk diameter }}
$$

f. Egg Quality Index (\%)

The egg quality index is obtained by comparing the egg's width to the egg's length measured using a caliper then multiplied by $100 \%$.

Data obtained were analyzed using variance (ANOVA) analysis and followed by the Duncan test with a confidence of 95\%. The analysis was performed with SPSS 16 for windows.

\section{RESULTS AND DISCUSSION}

The statistical analysis of the Japanese quail first egg's physical quality includes: egg weight, shell weight, yolk weight, albumen weight, egg quality index, and egg yolk index are presented in Table 2 . 
Jurnal Mangifera Edu, Volume 5, Issue 2, January 2021, 121-130

Table 2. Results of statistical analysis of the Japanese quail first egg (Coturnix japonica L.)

\begin{tabular}{lllll}
\cline { 2 - 4 } Parameter & \multicolumn{4}{c}{ Treatment } \\
& P0 & P1 & P2 & P3 \\
\hline Egg weight (gr) & $9.40^{\mathrm{a}} \pm 1.37$ & $9.55^{\mathrm{a}} \pm 0.68$ & $9.47^{\mathrm{a}} \pm 0.63$ & $10.05^{\mathrm{a}} \pm 1.13$ \\
Yolk weight (gr) & $2.42^{\mathrm{a}} \pm 0.63$ & $2.40^{\mathrm{a}} \pm 0.39$ & $2.53^{\mathrm{a}} \pm 0.29$ & $2.68^{\mathrm{a}} \pm 0.33$ \\
Albumen weight (gr) & $5.10^{\mathrm{a}} \pm 0.39$ & $5.45^{\mathrm{a}} \pm 0.30$ & $5.30^{\mathrm{a}} \pm 0.29$ & $5.65^{\mathrm{a}} \pm 0.79$ \\
Shell weight (gr) & $1.27^{\mathrm{a}} \pm 0.27$ & $1.22^{\mathrm{a}} \pm 0.29$ & $1.22^{\mathrm{a}} \pm 0.17$ & $1.48^{\mathrm{a}} \pm 0.69$ \\
Egg Quality Index (mm) & $83.41^{\mathrm{a}} \pm 5.10$ & $77.07^{\mathrm{a}} \pm 5.53$ & $79.56^{\mathrm{a}} \pm 2.46$ & $81.23^{\mathrm{a}} \pm 4.65$ \\
Yolk Index (mm) & $0.42^{\mathrm{a}} \pm 0.07$ & $0.44^{\mathrm{a}} \pm 0.06$ & $0.46^{\mathrm{a}} \pm 0.04$ & $0.44^{\mathrm{a}} \pm 0.04$ \\
\hline
\end{tabular}

Note: numbers followed by the same superscript in the same line show no significant difference $(\mathrm{P}>$ 0.05). P0: a control group with untreated drinking water, P1: treatment group with $3 \mathrm{ml}$ liquid herbal per 1 liter drinking water, P2: treatment group with $6 \mathrm{ml}$ liquid herbal per 1-liter drinking water, P3: treatment group with $9 \mathrm{ml}$ liquid herbal per 1 liter drinking water.

Result analysis of the weight of the first egg quail (45 days) given herbal ingredients showed that were not significantly different $(\mathrm{P}>0.05)$ in all of the treatment group including P0 (control) treatment; P1 (given herbal ingredients $3 \mathrm{ml}$ per 1 liter of drinking water); P2: (who are given herbal ingredients $6 \mathrm{ml}$ per 1 liter of drinking water); P3 (given 9ml of herbal concoctions per 1 liter of drinking water). The same results were also shown in albumen and yolk weights analysis, which showed no significant difference $(\mathrm{P}>0.05)$. The average weight of albumen and yolk in this study ranged from $5.10 \pm 0.39$ to $5.65 \pm 0.79$, while the average yolk weights were $2.42 \pm 0.63$ to $2.68 \pm 0.33$. According to Sumadja et al. (2019), the albumen weight was $6.28 \pm 0.31 \mathrm{~g}$ and yolk $2.96 \pm 0.15 \mathrm{gr}$. The herbal concoctions given did not directly affect egg components such as albumen and yolk formation, but herbal concoctions up to $9 \mathrm{ml}$ per 1 liter to drinking water did not have a negative effect on the weight of the egg albumen and yolk. Based on Fardiaz (1989), an egg compiler's main components consist of three parts, i.e., eggshell, egg white, and egg yolk. All three of these materials have masses that make up the weight of the egg. Yuwanta (2004) states that egg weight is affected by strain, age of sexual maturity, climate, and feed. Different strains in poultry cause differences in the age of sexual maturity.

Based on the analysis of quail eggshell, the result was not significantly different $(\mathrm{P}>0.05)$ in all treatment groups (P0, P1, P2, and P3). The average weight of eggshells of all treatments ranged from $1.22 \pm 0.17$ to $1.48 \pm 0.69$. This result is assumed that the calcium content in feed given to all treatments is equal to $0.90 \%$. In general, the function of calcium in livestock bodies acts as bone-building material (Tillman et al., 1984). According to Suprijatna et al. (2005), calcium plays a role in eggshell formation. Calcium consumption is 
affected by age, strain, feed consumption, and physiological status, while egg weight and eggshell thickness are affected by calcium consumption (Clunies et al., 1992).

The egg quality index results from comparing egg width and egg length in percent $(\%)$. Based on the statistical analysis results, the egg quality index showed no significantly different $(\mathrm{P}>0.05)$ results in all treatment groups. The egg quality index in this study ranged from $77.07 \pm 5.53$ to $83.41 \pm 5.10$. The egg quality index results obtained are still a general standard. Paryanta et al. (2019) state that the egg quality index with an average of $81.73 \%$. This is assumed to result from quails used originating from the same strain to produce eggs with relatively the same egg index genetically. Romanoff \& Romanoff (1963) state that each quail produces a unique egg shape because the egg shape is an inherited trait.

The yolk index (IKT) is obtained from a ratio between height and yolk diameter. The IKT statistical analysis results showed not significantly different $(\mathrm{P}>0.05)$ results in all treatment groups. The IKT in this study ranged from $0.42 \pm 0.07$ to $0.46 \pm 0.04$. The average yolk index in this study was relatively the same is because the protein content in the feed for all treatments is the same 20.00-22.00\%. Egg yolk index is influenced by protein in the feed. According to Standar Nasional Indonesia (2006), the yolk index consists of three levels of quality, namely quality $1(0.458-0.521 \mathrm{~mm})$, quality $2(0.394-0.457 \mathrm{~mm})$, and quality 3 $(0.330-0.393 \mathrm{~mm})$. Based on the study results, the average egg yolk index value in Table 2. ranged from $0.42 \pm 0.07$ to $0.46 \pm 0.04$, which means it is included in the quality two categories (0.394-0.457 mm). Meanwhile, according to the study by Genchev (2012), the yolk index of quail at the age of one day was 0.52. Chang et al. (1974) also stated that mineral deficiency in the feed could affect quail growth, decreased egg production, and cannibalism, which reduces overall production. Meanwhile, Rath et al. (2015) argue that the yolk index is an index of freshness quality measured by the egg yolk's height and diameter. According to Roberts (2004), this is the opinion that egg quality is influenced by several factors, i.e., storage, poultry strain, age, molting, feed nutrition, and disease.

\section{CONCLUSION}

This study could be concluded that the addition of herbal concoction with the treatment of $3 \mathrm{ml}, 6 \mathrm{ml}$, and $9 \mathrm{ml}$ per 1 liter of drinking water on the physical quality of the first egg of Japanese quail (Coturnix japonica L.), including egg weight, yolk weight, albumen weight, shell weight, egg quality index, and yolk index statistically showed results were not significantly different $(\mathrm{P}>0.05)$, but the addition of herbal concoction did not have 
Jurnal Mangifera Edu, Volume 5, Issue 2, January 2021, 121-130

a negative effect on the physical quality of the first eggs of Japanese quail (Coturnix japonica L.).

\section{ACKNOWLEDGEMENT}

We want to show our gratitude to the Ministry of Research and Technology and Institute for Research and Community Service (LPPM) of Al-Azhar Islamic University, Mataram, for funding this study and the people who supported and involved in it the process of implementing this study.

\section{REFERENCES}

Agustina, L., Syahrir, S., Purwanti, S., Jillbert, J., Asriani, A., \& Jamilah, J. (2017). Ramuan Herbal pada Ayam Ras Petelur Kabupaten Sidenreng Rappang. Jurnal Abdimas, 21(1), $47-54$.

Anjusha, S., \& Gangaprasad, A. (2014). Phytochemical and Antibacterial Analysis of Two Important Curcuma Species, Curcuma aromatica Salisb. and Curcuma xanthorrhiza Roxb.(Zingiberaceae). Journal of Pharmacognosy and Phytochemistry, 3(3), 50-53.

Basri, H, Saraswati, T. R., \& Isdadiyanto, S. (2018). Hematological Status of Rats (Rattus norvegicus L.) in the Lactation Period After Giving Supplements Organic Quail Eggs. International Journal of Biological Research, 6(1), 1-4.

Basri, Hasan, \& Swandayani, R. E. (2019). Pemberian Formula Pakan Herbal terhadap Profil Lipid pada Ayam Pedaging. MEDIA BINA ILMIAH, 13(12), 1847-1854.

Çabuk, M., Eratak, S., Alçicek, A., \& Bozkurt, M. (2014). Effects of Herbal Essential Oil Mixture as a Dietary Supplement on Egg Production in Quail. The Scientific World Journal, 2014.

Chang, C. H., Falen, L., \& Jensen, L. S. (1974). Effect of Maternal Diet on the Response of Japanese Quail to Purified and Practical Diets. Poultry Science, 53(1), 265-272.

Clunies, M., Parks, D., \& Leeson, S. (1992). Calcium and Phosphorus Metabolism and Eggshell Formation of Hens Fed Different Amounts of Calcium. Poultry Science, 71(3), 482-489.

Dudusola, I. O. (2010). Comparative Evaluation of Internal and External Qualities of Eggs from Quail and Guinea Fowl. International Research Journal of Plant Science, 1(5), $112-115$.

El-Sakka, M. A. (2010). Phytochemistry (3) alkaloids. Al Azhar University.

Fardiaz, S. (1989). Analisis Mikrobiologi Pangan Petunjuk Laboratorium. Institut Pertanian Bogor. Bogor.

Genchev, A. (2012). Quality and Composition of Japanese Quail Eggs (Coturnix japonica). https://jurnal.biounwir.ac.id/index.php/mangiferaedu| 128 
Jurnal Mangifera Edu, Volume 5, Issue 2, January 2021, 121-130

Trakia Journal of Sciences, 10(2), 91-101.

Harmono, S. T. P., \& Andoko, A. (2005). Budi Daya \& Peluang Bisnis Jahe. AgroMedia.

Lodang, E. M. F. R., Dewi, G. A. M. K., \& Nuriyasa, I. M. (2020). The Effect of Giving Betel Leaf Extract (Piper betel L.) on the Production and Quality of Broiler Carcasses. International Journal of Life Sciences, 4(1), 19-25.

McBride, R. S., Somarakis, S., Fitzhugh, G. R., Albert, A., Yaragina, N. A., Wuenschel, M. J., Alonso-Fernández, A., \& Basilone, G. (2015). Energy Acquisition and Allocation to Egg Production in Relation to Fish Reproductive Strategies. Fish and Fisheries, 16(1), 23-57.

Mughal, M. H. (2019). Turmeric polyphenols: A Comprehensive Review. Integr. Food Nutr. Metab, 6.

Nasution, A. S. (2017). Kualitas Telur Pertama Burung Puyuh (Coturnix coturnix javonica) dengan PemberianTepung Daun Pepaya (Carica papaya L) Dalam Ransum. Jurnal Peternakan (Jurnal of Animal Science), 1(1), 34-41.

Paryanta, P., Sudrajat, D., \& Anggraeni, A. (2019). The Quality of Quail (Coturnix-coturnix japonica) Egg Given Moringa Leaf Solution (Moringa oleifera L). JURNAL PETERNAKAN NUSANTARA, 5(1), 13-20.

Rath, P. K., Mishra, P. K., Mallick, B. K., \& Behura, N. C. (2015). Evaluation of Different Egg Quality Traits and Interpretation of Their Mode of Inheritance in White Leghorns. Veterinary World, 8(4), 449.

Rinawidiastuti, R., Fadhiliya, L., \& Ngatman, T. (2019). Produktivitas Burung Puyuh (Coturnix coturnix japonica) Pengaruh Subtitusi Sari Jahe Gajah (Zingiber officinale Rosc) Pada Air Minum. Surya Agritama: Jurnal Ilmu Pertanian Dan Peternakan, 8(1), $1-11$.

Roberts, J. R. (2004). Factors Affecting Egg Internal Quality and Egg Shell Quality in Laying Hens. The Journal of Poultry Science, 41(3), 161-177.

Romanoff, A. L., \& Romanoff, A. J. (1963). The Avian Egg John Wiley and Sons Inc. New York. Chapman \& Hill Limited London.

Rukayadi, Y., \& Hwang, J. (2007). In vitro Antimycotic Activity of Xanthorrhizol Isolated from Curcuma Xanthorrhiza Roxb. Against Opportunistic Filamentous Fungi. Phytotherapy Research: An International Journal Devoted to Pharmacological and Toxicological Evaluation of Natural Product Derivatives, 21(5), 434-438.

Saputro, V. T. (2011). Manajemen Pemeliharaan Burung Puyuh (Coturnix-Coturnix Japonica) Di Peternakan Agri Bird Jaten Karanganyar.

Saraswati, T. R., Manalu, W., Ekastuti, D. R., \& Kusumorini, N. (2013). The Role of Turmeric Powder in Lipid Metabolism and Its Effect on Quality of the First Quail's Egg. Journal of The Indonesian Tropical Animal Agriculture, 38(2), 123-130. 
Setyanto, A., Atmomarsono, U., \& Muryani, R. (2012). Pengaruh Penggunaan Tepung Jahe Emprit (Zingiber officinale var Amarum) dalam Ransum terhadap Laju Pakan dan Kecernaan Pakan Ayam Kampung Umur 12 Minggu. Animal Agriculture Journal, 1(1), 711-720.

Standar Nasional Indonesia. (2006). Pakan Puyuh Bertelur (Quail Layer). Badan Standardisasi Nasional, Jakarta.

Sukoco, A., Kusumaningrum, H. D., \& Suyatma, N. E. (2019). A Review on Biological Activities of Papaya (Carica papaya L.) Leaves extract and Its Potency as an Active Substance in the Food Packaging. International Food Research Journal, 26(6), 16651676.

Sumadja, W. A., Resmi, R., \& Atdhenan, M. (2019). Penggunaan Bungkil Kepayang (Pangium edule-reinw) dalam Ransum terhadap Kualitas Telur Puyuh (Coturnix coturnix japonica). Prosiding Seminar Nasional Pakar, 1-25.

Suprijatna, E., Atmomarsono, U., \& Kartasudjana, R. (2005). Ilmu Dasar Ternak Unggas. Penebar Swadaya, Jakarta, 227.

Suripta, H., \& Astuti, P. (2007). The Effects of Sardine and Palm Oil in Rations on the Ratio of Omega-3 to Omega-6 Fatty Acids in Eggs of Coturnix coturnix japonica. Journal of the Indonesian Tropical Animal Agriculture, 32(1), 22-27.

Tillman, A. D., Hartadi, H., Reksohadiprojo, S., Prawiro Kusumo, S., \& Lebdosukojo, S. (1984). Ilmu Makanan Ternak Dasar (p. 422). Yogyakarta: Gajah Mada University Press.

Widodo, R. W. (2019). The Effect of Chicken Manure Dose on Growth and Yield of Big Red Beans (Phaseolus vulgaris. L). JURNAL PERTANIAN, 10(2), 71-79.

Yair, R., \& Uni, Z. (2011). Content and Uptake of Minerals in the Yolk of Broiler Embryos during Incubation and Effect of Nutrient Enrichment. Poultry Science, 90(7), 15231531.

Yuwanta, T. (2004). Dasar Ternak Unggas. Kanisius.

Zurahmah, N. (2000). Manfaat Fitobiotik untuk Ternak Unggas. Makalah Ilmu Nutrisi Ternak Lanjut. Universitas Gadjah Mada Yogjakarta, 25. 